\title{
A HELYI TERMÉKEK FOGYASZTÓI PREFERENCIÁINAK VIZSGÁLATA
}

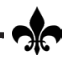

EXAMINING CONSUMER PREFERENCES OF LOCAL PRODUCTS

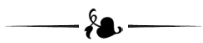

T. NAGY-PETÖ, DORKA

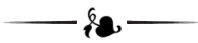

Debreceni Egyetem, Gazdaságtudományi Kar, Marketing és Kereskedelem Intézet (University of Debrecen, Faculty of Economics and Business, Institute of Marketing and Commerce) 4032 Debrecen, Böszörményi út 138 e-mail: peto.dorka@econ.unideb.hu

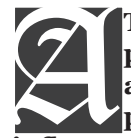

Today, the role of local products and short supply chains seems to be appreciating. The positive effects of buying local products also boost consumer commitment to these products and affect their competitiveness in local economies. The research examines consumer preferences related to local products, in which I explored the factors that fundamentally influence consumers when making their purchasing decisions. The research takes into account not only the arguments for the local product, but also against its purchase, as well as where to find information about local foods and which types are most sought after in local producer markets. The research is based on a nationally representative sample of 500 people, and those selected for the sample were selected by a random sampling procedure. Based on the results, it can be concluded that identifying the place of origin, health, and support of local producers are the most important motivating factors among the respondents. In addition, direct reference persons and local producers - play a prominent role among the sources of information, while other sources are hardly decisive when considering purchasing decisions. In producer markets, some commodity groups are outstandingly popular (vegetables, fruit, eggs), while in others product categories are dominated by traditional retail (animal or packaged products).

KuLCSSZAVAK: helyi termék, rövid ellátási lánc, termelö, termelői piac

JEL-KóDOK (JEL CODES): E21, M21, O13

DOI: https://doi.org/10.20494/TM/8/2/5

\section{BeVEZETÉS - INTRODUCTION}

A helyi termékek és a rövid ellátási láncok felértékelődését hozta világszerte a koronavírus-járvány. Bizonyos területeken ezt nemcsak a helyi gazdaság támogatása, de a nemzetközi kereskedelem leállítása is indokolta, ami az élelmiszer ellátási láncok átalakulását, újragondolását eredményezte (CAVALLO et al., 2020; FEI et al., 2020; HAILU, 2020). Fogyasztói oldalról az élelmiszerbiztonság kérdése is meg-
KEYWORDS: local product, short supply chain, producer, producer market 
termékek vásárlásakor a termékek jellemzően frissebbek, a zöldségek és gyümölcsök hoszszabb ideig érhetnek természetes módon, a termelő és a fogyasztó közötti bizalmi kapcsolat erősödik, megjelennek környezetkímélőbb előállítási és szállítási módszerek, emellett a helyi termékek értékesítése előnyösen hat a helyi gazdaságok árbevételének alakulására (NAK, 2016).

\section{SZAKIRODALMI ÁTTEKINTÉS - LITERATURE REVIEW}

A helyi termékek jellemzően a rövid ellátási láncokon keresztül jutnak el a fogyasztókhoz, ez kiemelten igaz az élelmiszerjellegü termékekre. A rövid élelmiszerellátási láncoknak három felfogása közismert: a közvetlen értéke- sítés, a közösségi marketingalapú értékesítés és a kiterjesztett ellátási lánc (RENTING et al., 2003; BENEDEK és BALÁZS, 2014). Ezeken belül számos változatot ismerhetünk a nagy hagyományokkal rendelkező termelői - vagy termelői részleggel kiegészített piacoktól egészen a hub- vagy védjegyrendszerekig.

A legtöbb országban már az elmúlt évtizedben egyre népszerúbbé váltak a helyi termékek. Ezt az egyes országokat vizsgáló önálló kutatások (GRANVIK et al., 2017; FOODNAVIGATOR, 2018; IRI, 2018; JENSEN et al., 2019; WUNSCH, 2020; SRD, 2020) is megerősítik. WUNSCH (2019) nemzetközi felmérései szerint (1. ábra) a helyi termékeket preferálók aránya Romániában $79 \%$, Svédországban $71 \%$, Olaszországban 70\%, míg Magyarországon $69 \%$. A vizsgált 11 ország közül Nagy Britannia és Belgium a „sereghajtó” 51-51\%-kal.

\section{1. ÁBRA}

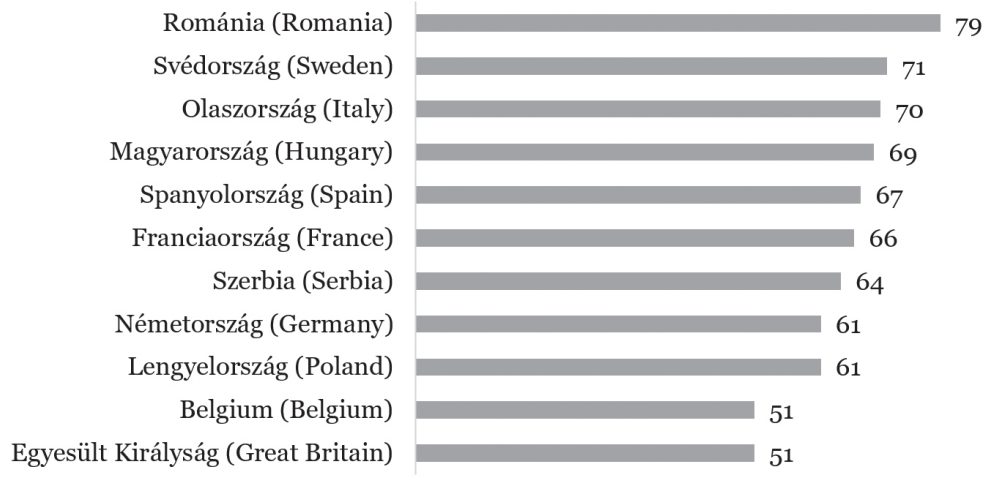

A helyi termékeket preferálók aránya az egyes országokban, \%

(Frequencies of Prefering Local Products in Each Country, \%)

Forrás (Source): WUNSCH (2019) alapján saját szerkesztés (Author's own compilation based on WUNSCH, 2019)

Egy dán kutatás két olyan fogyasztói csoportot azonosított, amelyek erősen elkötelezettek a helyi termékek vásárlása iránt, ők a vizsgált minta 38\%-át tették ki (JENSEN et al., 2019).

A helyi termékek előnyben részesítésének okai között megjelenik a jó minőség (CONNER et al., 2010, MEGICKS et al., 2012), az ételek által terjesztett betegség elkerülése, az élelmiszerbiztonság (CONNER et al., 2010), a helyi termelők támogatása (társadalmi felelősségvállalás), az etikusság (CARRIGEN és PLES-
MACKER, 2009; CARRINGTON et al., 2010; CONNER et al., 2010, MEGICKS et al., 2012), a pozitív hozzáadott érték (CONNER et al., 2010), továbbá a környezetvédelem lehetősége (MEGICKS et al., 2012). Összefüggést találtak az organikus, a friss és a prémium ételek előnyben részesítése (WEATHERELL et al., 2003; TREAGEAR és NESS, 2005; MIRANDA és LAWSON, 2012; HEMPEL és HAMM, 2016), az egészségtudatosság, általánosságban a tudatos vásárlás és a helyi termékek preferenciája között (MIRANDA és LAWSON, 2012). 
A leginkább fogékony fogyasztói közösségnek a helyi termékek iránt a fiatal-középkorú (30-40 éves), jó anyagi háttérrel rendelkező, iskolázottabb emberek tekinthetők (FOODNAVIGATOR, 2018). HENSELEIT és szerzőtársai (2007) német vizsgálatában azonban ezek a demográfiai jellemzők nem voltak relevánsak, itt a kognitív és a normatív tényezők befolyását találták erősebbnek.

A felárfizetési hajlandóság a helyi termékek iránt kutatásonként és országonként eltérő. Amíg egyes kutatásokban megjelenik a hajlandóság a felár megfizetésére (SHAHBANDEH, 2020), addig más kutatásokban az ár a legfontosabb visszatartó erő (HENSELEIT et al., 2007; BROWN et al., 2009; KHAN és PRIOR, 2010; MEGICKS et al., 2012). További akadályként azonosították a nehéz elérhetôséget és a szúk termékválasztékot (KHAN és PRIOR, 2010; MEGICKS et al., 2012).

Bár a helyi termékek kapcsán számos tényező akadályként jelenik meg, mégis érdemes hangsúlyozni, hogy az etikusság és a társadalmi felelősségvállalás racionális érvei mellett a helyi termékvásárlásnak emocionális és szórakozási aspektusa is van. Maga a vásárlás - az alapfunkcióján túl - magában hordozza ezeket az elemeket (non-functional outcomes) (MEGICKS et al., 2012; HIRSCHMAN és HOLBROOK, 1982; BABIN et al., 1994), így a szupermarketekben történő helyi termék vásárlás mellett érdemes kiemelni a ma már divatossá váló termelői piacokon történő beszerzést, melynek számos előnyét élvezik a fogyasztók (ARNOLD és REYNOLDS, 2003; WOODRUFFE-BURTON és WAKENSHAW, 2011). Ha a termelői piacok számának növekedése ezt nem erősítené meg (USDA, 2020; NÉBIH, 2018; COPPOLA, 2020; ENGELMANN, 2020), akkor hivatkozhatunk ezen értékesítési forma médiumokban való népszerüségére (kikapcsolódás, divat, tudatosság, státuszfogyasztás). Magyarországon a termelői piacok múködése szigorú, törvényileg szabályozott formában zajlik, amit indokol, hogy 2012 óta számuk drasztikusan megnőtt, és további növekedés várható a jövőben (NÉBIH, 2018; AGRÁRSZEKTOR, 2020).

A helyi termékekkel és szolgáltatásokkal kapcsolatban újabb trendként jelenik meg az online értékelés fontossága (KURNIA et al., 2018) a vásárlás előtt és után. A visszajelzések komoly hatással vannak a helyi vállalkozások termékeinek és szolgáltatásainak megítélésére (BRIGHT IDEAS, 2020). Ehhez kapcsolódik a járvány révén tovább erősödő - online helyi termékvásárlás iránti igény is (CAVALLO et al., 2020) Az előrejelzések szerint például Lengyelországban az élelmiszervásárlás 40\%-át 2026ra (a jelenlegi 7\%-hoz képest) online módon fogják lebonyolítani a fogyasztók (BARSKA és WOJCIECHOWSKA-SOLIS, 2020). Ezt a NIELSEN (2019) felmérései nemzetközi szinten is megerősítik.

\section{ANYAg ÉS MóDSZERTAN -} MATERIAL AND METHOD

A vizsgált témakörök összefüggéseinek feltárása érdekében egy 500 fős országos reprezentatív (nem, kor, településtípus, régió) fogyasztói kérdőíves megkérdezést folytattunk 2019-ben. A mintavétel az ún. véletlen séta (random walking) elvén alapult, míg a születésnapi kulcs segítségével második lépésben is biztosítottuk a véletlenszerüséget. Az adatfelvétel személyes megkérdezéssel történt egy standardizált kérdőív alapján.

A kérdőíven elsőként rákérdeztünk arra, hogy ki az, aki vásárol helyi terméket (403 fö, 80,6\%), illetve ki az, aki nem (97 fó, 19,4\%). Ezt követően két kérdésblokkot fogalmaztunk meg a helyi termék vásárlók (18 állítás), illetve a helyi terméket nem vásárlók számára (11 állítás) MEGICKS, MEMERY és ANGELL (2012) validált állítássora alapján. Az állításokat minden esetben 1-5 fokozatú Likert-skálán értékelték a kitöltők, ahol az 1, az egyáltalán nem ért egyet, míg az 5, a teljes mértékben egyetért válaszlehetőség volt. A továbbiakban megkérdeztük a válaszadókat a helyi élelmiszerválasztási szokásaikról, az igénybe vett információforrásokról és a preferált terméktípusokról a termelői piacok vonatkozásában. A kérdőív végére kerültek a szocio-demográfiai háttérváltozók: nem, kor, iskolai végzettség, szubjektív jövedelemérzet, településtípus, régió.

Az adatokat leíró statisztikai és a kereszttábla elemzésekkel vizsgáltuk meg.

A minta összetételét az 1. táblázat mutatja be. A népesség összetételének bemutatása segít a reprezentativitás igazolásában. 
A minta szociodemográfiai változók mentén történó bemutatása (The Socio-Demographic Background of the Sample)

\begin{tabular}{|c|c|c|c|}
\hline \multirow[t]{2}{*}{ Változók (Label) } & \multicolumn{2}{|c|}{$\begin{array}{c}\text { Minta } \\
\text { összetétele } \\
\text { (Sample } \\
\text { Distribution) }\end{array}$} & \multirow{2}{*}{$\begin{array}{c}\begin{array}{c}\text { Népesség } \\
\text { összetétele } \\
\text { (Population } \\
\text { Distribution) }\end{array} \\
\%\end{array}$} \\
\hline & $\begin{array}{c}\text { Fő } \\
\text { (Count) }\end{array}$ & $\%$ & \\
\hline Férfi (Male) & 235 & 47,0 & 47,8 \\
\hline Nő (Female) & 265 & 53,0 & 52,2 \\
\hline 16-29 év (years) & 96 & 19,2 & 18,3 \\
\hline 30-39 év (years) & 83 & 16,6 & 16,0 \\
\hline 40-49 év (years) & 93 & 18,5 & 19,6 \\
\hline 50-59 év (years) & 73 & 14,7 & 15,1 \\
\hline $60+$ év (years) & 155 & 31,0 & 31,0 \\
\hline Budapest & 90 & 18,0 & 17,9 \\
\hline Város (Town) & 275 & 55,0 & 52,6 \\
\hline Község, falu (Village) & 135 & 27,0 & 29,5 \\
\hline Maximum általános iskola (Primary school) & 64 & 12,9 & \\
\hline Szak-, szakközépiskola (Vocational school) & 154 & 30,7 & \\
\hline Gimnázium (Secondary Grammar school) & 202 & 40,5 & \\
\hline Felsőoktatás (Higher education) & 80 & 15,9 & \\
\hline $\begin{array}{l}\text { Megélünk jövedelmünkből és a még félre is tudunk tenni (Can make ends meet and can } \\
\text { also save) }\end{array}$ & 35 & 7,0 & \\
\hline $\begin{array}{l}\text { Megélünk jövedelmünkből, de keveset tudunk félretenni (Can make ends meet, but can } \\
\text { save little) }\end{array}$ & 175 & 35,0 & \\
\hline $\begin{array}{l}\text { Éppen elegendô a megélhetésre, de félretenni már nem tudunk (Just enough to make } \\
\text { ends meet, but cannot save) }\end{array}$ & 241 & 48,2 & \\
\hline $\begin{array}{l}\text { Néha arra sem elegendő a jövedelmünk, hogy megéljünk belőle (Sometimes cannot make } \\
\text { ends meet) }\end{array}$ & 22 & 4,4 & \\
\hline Rendszeresen anyagi problémákkal küzdünk (Have regular financial problems) & 1 & 0,2 & \\
\hline Nem tudja/nem válaszolt (Do not know/No answer) & 26 & 5,2 & \\
\hline
\end{tabular}

Forrás (Source): Saját szerkesztés (Author's own compilation)

Megjegyzés (Notes): ${ }^{1} \mathrm{~A}$ reprezentativitás biztosításának alapja (Basis of ensuring representativeness) (Source of data): KSH 2019a; 2019b.

\section{EREDMÉNYEK - RESUlts}

\subsection{A helyi termékek választásának okai - Reasons of Choosing Local Products}

Először az egyes állítások alapvető statisztikai mutatóit szemléltetjük (2. táblázat). Az eredmények szerint a helyi termékek választásának három leginkább támogatott oka a származási hely azonosíthatósága, az egészségesség és a helyi termelők támogatása, amelyek megegyeznek a korábban közölt kutatási eredményekkel (CARRIGAN és PLESMACKER, 2009; CAR-
RINGTON et al., 2010; CONNER et al., 2010, MEGICKS et al., 2012; MIRANDA és LAWSON, 2012). Bár az első 11 állításnál a módusz minden esetben 5 , azonban a további állításoknál már egyre nagyobb a heterogenitás. A kitöltők a legkevésbé a helyi termékvásárlás szórakoztató mivoltával, illetve a büntudat érzetével azonosultak. A módusz ezekben az esetekben 1. Ugyanakkor a nosztalgiaérzet sem befolyásolja lényegesen a fogyasztók helyi termékvásárlási szokásait szemben más nemzetközi kutatási eredményekkel, ahol a bűntudat és a nosztalgia szintén nyomós okként szerepeltek (MEGICKS et al., 2012). 
Helyi termékek választásának okai, $\mathrm{N}=403$

(Reasons for Choosing Local Products, $\mathrm{N}=403$ )

Statisztikai mutató (Statistical indicator)

\section{Attitüd állítások (Attitude statements)}

\begin{tabular}{ccccc}
\hline $\begin{array}{c}\text { Átlag } \\
\text { (Mean) }\end{array}$ & $\begin{array}{c}\text { Medián } \\
\text { (Median) }\end{array}$ & $\begin{array}{c}\text { Módusz } \\
\text { (Mode) }\end{array}$ & $\begin{array}{c}\text { Szórás } \\
\text { (Standard } \\
\text { Deviation) }\end{array}$ & $\begin{array}{c}\text { Ferdeség } \\
\text { (Skewness) }\end{array}$ \\
\hline
\end{tabular}

\begin{tabular}{|c|c|c|c|c|c|}
\hline $\begin{array}{l}\text { Azért veszek helyi termékeket, mert így tudom, hogy honnan } \\
\text { származik a termék (I buy local produce, because I know } \\
\text { where it comes from) }\end{array}$ & 4,55 & 5,00 & 5 & 0,724 & $-1,871$ \\
\hline $\begin{array}{l}\text { Azért veszek helyi termékeket, mert azok egészségesek (I buy } \\
\text { local produce, because it is wholesome) }\end{array}$ & 4,22 & 5,00 & 5 & 1,023 & $-1,634$ \\
\hline $\begin{array}{l}\text { Azért veszek helyi termékeket, mert ezzel támogatom a helyi } \\
\text { termelőket (I buy local produce, because it supports local } \\
\text { producers) }\end{array}$ & 4,20 & 4,00 & 5 & 0,968 & $-1,273$ \\
\hline $\begin{array}{l}\text { Azért veszek helyi termékeket, mert annyit vehetek belölük, } \\
\text { amennyire éppen szükségem van (I buy local produce, be- } \\
\text { cause I can buy the amount I want) }\end{array}$ & 4,18 & 5,00 & 5 & 1,080 & $-1,451$ \\
\hline $\begin{array}{l}\text { Azért veszek helyi termékeket, mert jó tapasztalataim vannak } \\
\text { a vásárlással kapcsolatban (I buy local produce, because the } \\
\text { shopping experience is satisfying) }\end{array}$ & 4,16 & 4,00 & 5 & 1,051 & $-1,430$ \\
\hline $\begin{array}{l}\text { Azért veszek helyi termékeket, mert azok természetes élelmi- } \\
\text { szerek (I buy local produce, because it is natural) }\end{array}$ & 4,16 & 4,00 & 5 & 1,075 & $-1,562$ \\
\hline $\begin{array}{l}\text { Azért veszek helyi termékeket, mert azok nem tartalmaznak } \\
\text { tartósítószereket (I buy local produce, because it is free from } \\
\text { preservatives) }\end{array}$ & 4,12 & 5,00 & 5 & 1,187 & $-1,502$ \\
\hline $\begin{array}{l}\text { Azért veszek helyi termékeket, mert ezzel csökkenteni lehet az } \\
\text { élelmiszerek szállítási távolságát (I buy local produce, because } \\
\text { it reduces food miles) }\end{array}$ & 4,07 & 4,00 & 5 & 1,118 & $-1,246$ \\
\hline $\begin{array}{l}\text { Azért veszek helyi termékeket, mert ezzel támogatom a helyi } \\
\text { eladókat (kereskedőket) (I buy local produce, because it } \\
\text { supports local retailers) }\end{array}$ & 4,06 & 4,00 & 5 & 1,081 & $-1,149$ \\
\hline $\begin{array}{l}\text { Azért veszek helyi termékeket, mert azok jól néznek ki (I buy } \\
\text { local produce, because it has a good appearance) }\end{array}$ & 3,82 & 4,00 & 5 & 1,205 & $-0,938$ \\
\hline $\begin{array}{l}\text { Azért veszek helyi termékeket, mert azok nem tartalmaznak } \\
\text { vegyszereket (I buy local produce, because it is free from } \\
\text { chemicals) }\end{array}$ & 3,76 & 4,00 & 5 & 1,256 & $-0,959$ \\
\hline $\begin{array}{l}\text { Azért veszek helyi termékeket, mert azok környezetbarát } \\
\text { termékek (I buy local produce, because it is environmentally } \\
\text { friendly) }\end{array}$ & 3,76 & 4,00 & 4 & 1,232 & $-1,094$ \\
\hline $\begin{array}{l}\text { Azért veszek helyi termékeket, mert azok tovább eltarthatók ( } \\
\text { buy local produce, because it lasts longer) }\end{array}$ & 3,68 & 4,00 & 5 & 1,268 & $-0,800$ \\
\hline $\begin{array}{l}\text { Azért veszek helyi termékeket, mert ez etikus cselekedet (I buy } \\
\text { local produce, because it is ethical) }\end{array}$ & 3,30 & 3,00 & 3 & 1,337 & $-0,365$ \\
\hline $\begin{array}{l}\text { Azért veszek helyi termékeket, mert ez visszaidézi a régi idők } \\
\text { emlékeit (I buy local produce because shopping, because it } \\
\text { brings back memories of the past) }\end{array}$ & 3,30 & 3,00 & 4 & 1,388 & $-0,385$ \\
\hline $\begin{array}{l}\text { Azért veszek helyi termékeket, mert nosztalgiát keltenek ben- } \\
\text { nem (I buy local produce, because it is nostalgic) }\end{array}$ & 3,05 & 3,00 & 3 & 1,410 & $-0,157$ \\
\hline $\begin{array}{l}\text { Azért veszek helyi termékeket, mert ez számomra szórakoztató } \\
\text { (I buy local produce, because shopping for it is fun) }\end{array}$ & 2,78 & 3,00 & 1 & 1,460 & 0,141 \\
\hline $\begin{array}{l}\text { Azért veszek helyi termékeket, mert bủntudatot éreznék, ha } \\
\text { nem tennék így (I buy local produce, because I feel guilty if I } \\
\text { do not) }\end{array}$ & 2,24 & 2,00 & 1 & 1,446 & 0,748 \\
\hline
\end{tabular}

Forrás (Source): Saját szerkesztés (Author’s own compilation) 
Kereszttábla vizsgálatokkal elemeztük az egyes állítások egymással kapcsolatos öszszefüggését, melynél minden esetben szignifikáns összefüggést találtunk (minden esetben $\mathrm{p}<0,001)$ a korábban említett heterogenitás esélye mellett is. Amely állítások magasabb átlaggal rendelkeznek, ott pozitív együttmozgás figyelhető meg, míg a két módusz=1 állítás esetében (a helyi termék vásárlás szórakoztató, illetve bűntudatot érez, ha nem helyit terméket vásárol) ellentétes hatás látható a többi állítással.

\subsection{A helyi termékek elutasításának okai - Reasons of the Local Products' Rejection}

A MEGICKS és társai (2012) által elvégzett kutatással megegyezően elemeztük a nem-vásárlók (97 fó, 19,4\%) helyi termékelutasítási indokait (3. táblázat). Az elutasítás legfőbb okai a vélt extra idő- és energiaigény, a túlzottan sok utazás, a nehéz beszerezhetőség és a vásárlás kényelmetlensége. A nem-vásárlás indokai között a magas árszínvonal csak a hatodik helyre került. A módusz minden esetben 1, azaz a helyi termékek vásárlásának elutasítását a legtöbb esetben nem résztényezők, hanem alapvető idegenkedés vagy érdektelenség okozhatja.

helyi termékek nem választásának okai az azt elutasítók körében, $\mathrm{N}=10$
(Reasons for Not Choosing Local Products Among Rejecters, $N=106$ )

\begin{tabular}{|c|c|c|c|c|c|}
\hline \multirow[b]{2}{*}{$\begin{array}{l}\text { Attitúd állítások } \\
\text { (Attitude statements) }\end{array}$} & \multicolumn{5}{|c|}{ Statisztikai mutató (Statistical indicator) } \\
\hline & $\begin{array}{l}\text { Átlag } \\
\text { (Mean) }\end{array}$ & $\begin{array}{l}\text { Medián } \\
\text { (Median) }\end{array}$ & $\begin{array}{l}\text { Módusz } \\
\text { (Mode) }\end{array}$ & $\begin{array}{l}\text { Szórás } \\
\text { (Standard } \\
\text { Deviation) }\end{array}$ & $\begin{array}{c}\text { Ferdeség } \\
\text { (Skewness) }\end{array}$ \\
\hline $\begin{array}{l}\text { Azért nem veszek helyi termékeket, mert vásárlásuk túlzottan } \\
\text { időigényes (I don't buy local produce, because to do so, it is } \\
\text { time consuming) }\end{array}$ & 2,75 & 3,00 & 1 & 1,792 & 0,047 \\
\hline $\begin{array}{l}\text { Azért nem veszek helyi termékeket, mert a vásárlás túl sok } \\
\text { többlet energiával jár (I don't buy local produce, because it } \\
\text { requires extra effort) }\end{array}$ & 2,64 & 2,00 & 1 & 1,809 & 0,134 \\
\hline $\begin{array}{l}\text { Azért nem veszek helyi termékeket, mert túl sokat kell utaz- } \\
\text { nom értük (I don't buy local produce, because I have to travel } \\
\text { farther to do so) }\end{array}$ & 2,62 & 3,00 & 1 & 1,704 & 0,107 \\
\hline $\begin{array}{l}\text { Azért nem veszek helyi termékeket, mert azokat nehéz } \\
\text { beszerezni (I don't buy local produce, because it is not readily } \\
\text { available) }\end{array}$ & 2,60 & $3, \mathrm{OO}$ & 1 & 1,766 & 0,119 \\
\hline $\begin{array}{l}\text { Azért nem veszek helyi termékeket, mert a vásárlás kényelmet- } \\
\text { len (I don't buy local produce, because it is inconvenient) }\end{array}$ & 2,54 & 2,00 & 1 & 1,714 & 0,199 \\
\hline $\begin{array}{l}\text { Azért nem veszek helyi termékeket, mert azok túl drágák (I } \\
\text { don't buy local produce, because it is expensive) }\end{array}$ & 2,50 & 3,00 & 1 & 1,725 & 0,196 \\
\hline $\begin{array}{l}\text { Azért nem veszek helyi termékeket, mert azok nincsenek } \\
\text { eléggé jól reklámozva (I don't buy local produce, because it is } \\
\text { not well promoted) }\end{array}$ & 2,43 & 2,00 & 1 & 1,753 & 0,361 \\
\hline $\begin{array}{l}\text { Azért nem veszek helyi termékeket, mert a hagyományos } \\
\text { boltokban vásárolt termék jellemzően jobb (I don't buy local } \\
\text { produce, because food produced elsewhere is sometimes } \\
\text { better) }\end{array}$ & 2,13 & 2,00 & 1 & 1,481 & 0,645 \\
\hline $\begin{array}{l}\text { Azért nem veszek helyi termékeket, mert nincs rajtuk informa- } \\
\text { tív címke és feliratozás (I don't buy local produce, because it is } \\
\text { not well labelled) }\end{array}$ & 2,12 & 1,00 & 1 & 1,587 & 0,705 \\
\hline $\begin{array}{l}\text { Azért nem veszek helyi termékeket, mert kicsi a választék ( } I \\
\text { don't buy local produce, because the range of products is } \\
\text { limited) }\end{array}$ & 2,10 & 2,00 & 1 & 1,487 & 0,620 \\
\hline $\begin{array}{l}\text { Azért nem veszek helyi termékeket, mert az ár nem mindig } \\
\text { egyértelmű rajtuk (pl. hiányzik a vonalkód) (I don't buy local } \\
\text { produce, because the price is not always clear) }\end{array}$ & 2,07 & 1,00 & 1 & 1,602 & 0,771 \\
\hline
\end{tabular}

Forrás (Source): Saját szerkesztés (Author's own compilation) 


\subsection{A helyi termékekkel kapcsolatos előzetes információszerzés forrásai - Sources of Preliminary Information Collection}

További eredményeink alapján elmondható, hogy a helyi élelmiszerekkel kapcsolatos információforrások a közvetlen referenciaszemélyek (3. ábra). Az előzetes tájékozódási pont a megkérdezettek körében egyértelműen a szájreklám, azaz a családtagok (40,4\%) és a barátok (37,4\%) visszajelzései. Emellett a helyi termelőktől kapott információkra támaszkodnak még (40,4\%). Minden más forrás csupán 15\%-nál kevesebb említést kapott, azaz ezeknek figyelemfelkeltő hatása lehet, ám a ténylegesen elvárt információt közvetlen módon igyekeznek beszerezni.

\section{2. ÁBRA}

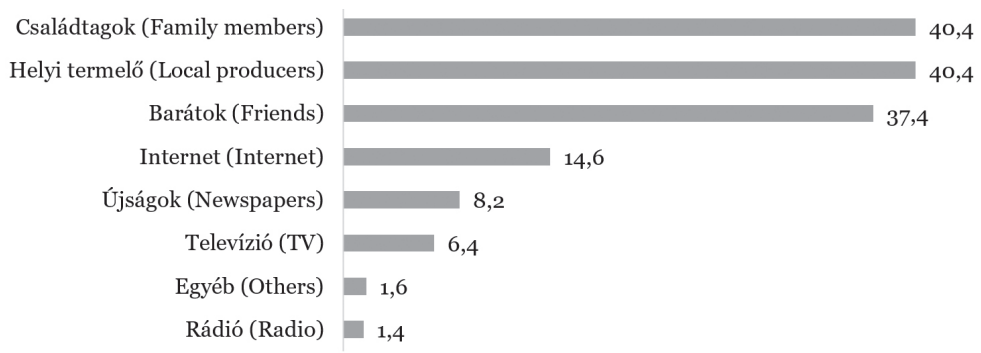

FIG. 2

Helyi élelmiszerekről való előzetes információgyưjtés forrásai (választotta, \%)

(Sources of Preliminary Information Gathering on Local Foods (\%))

Forrás (Source): Saját szerkesztés, 2021 (Author's own compliation, 2021) N=500, Többválasztásos kérdés (Multiple choice question)

\subsection{Preferált élelmiszertípusok a termelói piacokon - Preferred Product Types at the Local Producer Markets}

A termelői vagy termelői piaci részleggel kiegészült piacok esetében a leggyakrabban az élelmiszervásárlás kapcsán tehetünk említést. A 4. táblázat azt mutatja, hogy az egyes élelmiszertípusokat milyen gyakorisággal vásárolják a megkérdezettek. A napi és heti gyakoriságot összesítve láthatjuk, hogy a zöldség- (49,7\%) és a gyümölcsvásárlás (49,7\%) a leggyakoribb, ám a tojás- (29,8\%), a pékáru (27,7\%) és a tejvásárlás (25,3\%) is számottevőnek mondható. A húsáruk közül csak a szárnyas húsok emelkednek ki 14,9\%-kal. Ami meglepő lehet, hogy a megkérdezettek válaszai alapján a ritkán vagy soha kategóriába került a lekvár (91,1\%) és a méz (86\%), de a húsok közül a halak és a marhahús (>88\%) is a ritkán vásárolt kategóriába kerültek. 
4. TÁBLÁZAT

TABLE 4

Az egyes élelmiszer termékfajták vásárlási gyakorisága termelői vagy termelői részleggel

kibővített piacon kistermelöktól, \% $(\mathrm{N}=366)$

(Frequency of Purchases of Each Type of Food Product From Small Producers in Producer Market or Extended Traditional Market, \% $(N=366))$

\begin{tabular}{|c|c|c|c|c|c|c|}
\hline $\begin{array}{c}\text { Termékfajta (Product } \\
\text { Types)/Gyakoriság } \\
\text { (Frequency) }\end{array}$ & $\begin{array}{l}\text { Naponta } \\
\text { (Every } \\
\text { day) }\end{array}$ & $\begin{array}{c}\text { Hetente } 3-4 \\
\text { alkalommal } \\
\text { (3-4 times a } \\
\text { week) }\end{array}$ & $\begin{array}{l}\text { Hetente 1-2 } \\
\text { alkalommal } \\
\text { (1-2 times a } \\
\text { week) }\end{array}$ & $\begin{array}{l}\text { Havonta 1-2 } \\
\text { alkalommal } \\
(1-2 \text { times } a \\
\text { month) }\end{array}$ & $\begin{array}{c}\text { Ritkábban, } \\
\text { mint } \\
\text { havonta } \\
\text { (Rarely } \\
\text { than a } \\
\text { month) }\end{array}$ & $\begin{array}{c}\text { Soha } \\
\text { (Never) }\end{array}$ \\
\hline Zöldségek (Vegetables) & 2,4 & 6,8 & 40,5 & 25,6 & 19,3 & 5,4 \\
\hline Gyümölcsök (Fruits) & 3,9 & 6,3 & 39,6 & 25,9 & 18,5 & 6,0 \\
\hline Szárnyasok (Poultries) & 1,5 & 1,8 & 11,6 & 19,9 & 14,9 & 50,3 \\
\hline Halak (Fish) & 2,1 & 1,2 & 2,1 & 4,8 & 24,4 & 65,5 \\
\hline Marhahús (Beef) & 1,5 & 0,9 & 3,0 & 6,0 & 20,8 & 67,9 \\
\hline Sertéshús (Pork) & 1,2 & 1,2 & 9,2 & 15,5 & 16,7 & 56,3 \\
\hline Joghurt (Yoghurt) & 3,0 & 5,4 & 10,4 & 6,8 & 6,8 & 67,6 \\
\hline Sajt (Cheese) & 1,5 & 1,8 & 11,9 & 22,6 & 16,1 & 46,1 \\
\hline Tej (Milk) & 4,8 & 5,4 & 15,2 & 8,9 & 6,8 & 58,9 \\
\hline $\begin{array}{l}\text { Tejföl/kefír/túró (Sour cream/ } \\
\text { cottage cheese) }\end{array}$ & 2,4 & 3,0 & 13,7 & 14,9 & 11,9 & 54,2 \\
\hline Méz (Honey) & 0,3 & 0,3 & 1,5 & 11,9 & 61,6 & 24,4 \\
\hline Lekvár (Jam) & 1,5 & 0,0 & 1,5 & 6,0 & 26,5 & 64,6 \\
\hline Tojás (Egg) & 1,2 & 2,7 & 25,9 & 30,7 & 17,9 & 21,7 \\
\hline Tészta (Pasta) & 1,8 & 1,8 & 8,0 & 14,6 & 13,4 & 60,4 \\
\hline Pékáru (Bakery products) & 11,6 & 5,4 & 10,7 & 6,8 & 7,1 & 58,3 \\
\hline Savanyúság (Pickles) & 1,5 & 0,0 & 6,8 & 19,0 & 24,1 & 48,5 \\
\hline $\begin{array}{l}\text { Kolbász, szalonna (Sausage, } \\
\text { bacon) }\end{array}$ & 0,3 & 0,9 & 8,9 & 21,4 & 33,9 & 34,5 \\
\hline Hüvelyesek (Legumes) & 0,9 & 0,6 & 8,0 & 18,2 & 22,6 & 49,7 \\
\hline Csonthéjasok (Seeds) & 0,6 & 0,0 & 3,0 & 12,8 & 29,8 & 53,9 \\
\hline Füszerek (Spices) & 2,1 & 1,2 & 4,5 & 8,9 & 18,5 & 64,9 \\
\hline
\end{tabular}

Forrás (Source): Saját szerkesztés (Author's own compilation)

Megjegyzés (Notes): Az eredmények csak a termelői piacokon vásárló kitöltők véleményét mutatja (The results only show the opinion of participants buying in producer markets)

\section{KÖVETKEZTETÉSEK ÉS ÖSSZEFOGLALÁS - CONCLUSIONS AND SUMMARY}

A helyi termékek iránti igény az elmúlt évtizedben globálisan növekedett, és ezt a koronavírus-járvány a legtöbb országban még tovább erősítette (CAVALLO et al., 2020; FEI et al., 2020; GRANVIK et al., 2017; FOODNAVIGATOR, 2018; IRI, 2018; JENSEN et al., 2019; WUNSCH, 2020; SRD, 2020). A fogyasztói elvárások közül fontos kiemelni a minőség, a biztonság, a bizalom és az etikusság, illetve a (helyi) fenntarthatóság hívószavakat a helyi termékekre irányuló fogyasztói döntéshozatalban (CONNER et al., 2010; MEGICKS et al., 2012; CARRIGEN és PLESMACKER, 2009; GIAMPIETRI et al., 2018). A helyi termékek iránt leginkább elkötelezett szegmensek mind a tudatosság, mind a helyi termékek vásárlása kapcsán a középkorú, jó anyagi helyzetben lévô személyek. 
A kutatás alapján érdemes kiemelni, hogy az előzetes tájékozódási és információgyüjtési forrás a helyi termékek esetében a szájreklám, és minden további információforrás inkább csak figyelemfelkeltő, további tájékoztató funkcióval bír, megerősítve a helyi termékek bizalmi jellegét.

A legnépszerúbb élelmiszerkategóriáknak egyértelmüen a zöldség- és gyümölcsféléket nevezhetjük, majd ezeket a pékáruk és az állati eredetű termékek követik.

A kutatási eredményei alapján összességében kijelenthető, hogy a legmeghatározóbb érv a helyi termékek vásárlása mellett a származás ismeretéből fakadó biztonságérzet (helyi jelleg), az egészségvédő tulajdonságaikba vetett hit, illetve a helyi közösség támogatása.

A helyi termékek vonzerejének és vélt vagy valós pozitív tulajdonságainak, értékeinek felismerése a fogyasztói attitűdök mentén elősegítheti az állami döntéshozás, a közösségi agrármarketing-szervezetek, illetve a vállalkozók megfelelő piaci stratégiájának kialakítását. A helyi terméket nem-vásárlók megkérdezéséből kiderült, hogy többségüknél nem egy-egy, a szakirodalomból megismert akadályozó tényező áll az elutasítás hátterében, mint például az ár vagy az elérhetőség (SHAHBANDEH, 2020; HENSELEIT et al., 2007; BROWN et al., 2009; KHAN és PRIOR, 2010; MEGICKS et al., 2012), hanem komplexebb módon, több tényező együttesen a felelős az érdektelenségért.

\section{IRODALOMJEGYZÉK - REFERENCES}

Agrárszektor: Brutálisan megnőtt a termelői piacok száma Magyarországon. 2020. https://www.agrarszektor. $\mathrm{hu} / \mathrm{ag}$ rar penzek/brutalis a n megnott-a-termeloi-piacok-szamamagyarorszagon.19153.html (Letöltés dátuma: 2020.03.12.)

Arnold, M. J. - Reynolds, K. E.: Hedonic Shopping Motivations. Journal of Retailing. 2003.79(2) 77-95. DOI: https:// doi.org/10.1016/So022-4359(03)00007-1

Babin, B. J. - Darden, W. R. - Griffin, M.: Work and/or Fun: Measuring Hedonic Andutilitarian Shopping Value. Journal of Consumer Research. 1994. 20 (4) 411-423. DOI: https://doi.org/10.1086/209376
Barska, A. - Wojciechowska-Solis, J.: E-consumers and Local Food Products: A Perspective for Developing Online Shopping for Local Goods in Poland. Sustainabilty. 2020. (12) 4958. DOI: https://doi.org/10.3390/su12124958

Benedek, Zs. - Balázs, B.: A rövid ellátási láncok szocioökonómiai hatásai Külgazdaság. 2014. 58 (5-6) 100-120.

Bright Ideas: Local Consumer Review Survey 2020. 2020. https://www.brightlocal. $\mathrm{com} /$ research/local-consumer-reviewsurvey/ (Letöltés dátuma: 2021.10.12.)

Brown, E. - Dury, B. S. - Holdsworth, M. C.: Motivations of Consumers That Use Local, Organic Fruit and Vegetable Box Schemes in Central England and Southern France. Appetite 2009. 53 (2) 183-188. DOI: https://doi.org/10.1016/j. appet.2009.06.006

Carrigan, M. - de Pelsmacker, P.: Will Ethical Consumers Sustain Their Values in Theglobal Credit Crunch? International Marketing Review. 2009. 26 (6) 674-687. DOI: https://doi. org/10.1108/02651330911001341

Carrington, M. J. - Neville, B. A. Whitwell, G. J.: Why Ethical Consumers Don't Walk Their Talk: Towards a Framework for Understanding the Gap Between the Ethical Purchase Intentions and Actual Buying Behaviour of Ethically Minded Consumers. Journal of Business Ethics. 2020. 97 139-158. DOI: https:// doi.org/10.1007/s10551-010-0501-6.

Cavallo, C. - Sacch, G. - Carfora, V.: Resilience Effects in Food Consumption Behaviour at the Time of Covid-19: Perspectives From Italy. Heliyon. 2020. 6 (12) e05676. DOI: https://doi. org/10.1016/j.heliyon.2020.eo5676

Coluccia, B. - Agnusdei, G. P. - Miglietta, P. P. - De Leo, F.: Effects of COVID-19 on the Italian Agri-Food Supply and Value Chains. Food Control. 2021. 123. 107839. DOI: https://doi.org/10.1016/j. foodcont.2020.107839 
Conner, D. - Colasanti, K. - Ross, R. B. Smalley, S. B.: Locally Grown Foods and Farmers Markets: Consumer Attitudes and Behaviors. Sustainability. 2010. 2 (3) 742-756. DOI: https://doi.org/10.3390/ su2030742

Coppola, D.: Percentage Change of the Turnover of the Farm Shops and Farmers Market Flanders 2019. 2020. https:// www.statista.com/statistics/729250/ percentage-change-turnover-farm-shopsand-farmers-market-belgium/ (Letöltés dátuma: 2021.10.10.)

Engelmann, J.: Sales Value of Farmer's Markets in Japan FY 2013-2018. 2020. https://www.statista.com/ statistics / 1179443/japan-farmer-smarkets-sales-value/ (Letöltés dátuma: 2021.10.10.)

Fei, S. - Ni, J. - Santini, G.: Local Food Systems and COVID-19: An Insight from China. Resources, Conservation and Recycling. 2020.162.105022.DOI:https:// doi.org/10.1016/j.resconrec.2020.105022

FoodNavigator: Local Brands Are Winning Hearts and Minds: Rising Demand for Local Food in Europe. 2018. https://www. foodnavigator.com/Article/2018/11/14/ Local-brands-are-winning-hearts-andminds-Rising-demand-for-local-food-inEurope (Letöltés dátuma: 2021.10.10.)

Giampietri, E. - Verneau, F. - Del Giudice, T. - Carfora, V. - Finco, A.: A Theory of Planned Behaviour Perspective for Investigating the Role of Trust in Consumer Purchasing Decision Related to Short Food Supply Chains. Food Quality and Preference. 2018. 64 (March) 160-166. DOI: https://doi.org/10.1016/j. foodqual.2017.09.012

Granvik, M. - Joosse, S. - Hunt, A. - Hallberg, I.: Confusion and Misunderstanding - Interpretations and Definitions of Local Food. Sustainability. 2017. 9 (11) 1981. DOI: https://doi. org/10.3390/su9111981

Hailu, G.: Economic thoughts on COVID-19 for Canadian Food Processors. Canadian Journal of Agricultural Economics. 2020. 68 (2) 163-169. DOI: https://doi. org/10.1111/cjag.12241
Hempel, C. - Hamm, U.: How Important Is Local Food to Organic-Minded Consumers? Appetite. 2016. 96 309318. DOI: https://doi.org/10.1016/j. appet.2015.09.036

Henseleit, M. - Kubitzki, S. - Teuber, R.: Determinants of Consumer Preferences for Regional Food. Contributed Paper Prepared for Presentation at the 105th EAAE Seminar "International Marketing and International Trade of Quality Food Products", 2007. 55-67. DOI: https://doi. org/10.22004/ag.econ.7871

Hirschman, E. C. - Holbrook, M. B.: Hedonic Consumption: Emerging Concepts, Methods and Propositions. Journal of Marketing. 1982. 46 92-101. DOI: https://doi. org/10.1177/002224298204600314

IRI: IRI Appoints Olly Abotorabi to Newly Created Regional Market Insights Role. 2018. https://www.iriworldwide.com/ en-gb/insights/news/iri-appoints-ollyabotorabi-to-newly-created-regionalmarket-insights-role (Letöltés dátuma: 2021.10.11.)

Jensen, J. D. - Christensen, T. Denver, S. - Ditlevsen, K. - Lassen, J. - Teuber, R.: Heterogeneity in Consumers' Perceptions and Demand for Local (Organic) Food Products. Food Quality and Preference. 2019. 73 255265. DOI: https://doi.org/10.1016/j. foodqual.2018.11.002

Khan, F. - Prior, C.: Evaluating the Urban Consumer with Regard to Sourcing Local Food: A Heart of England Study. International Journal of Consumer Studies. 2010. 34 (2) 161-168. DOI: https://doi. org/10.1111/j.1470-6431.2009.00836.x

KSH: Time Series Of Annual Data Population, Vital Events/1.2. Population by Type of Settlement, 1 January (19802019), 1.3. Population By Sex And Age, 1 January (1980-2019). 2019a. http:// www.ksh. hu/stadat_annual_1, (Letöltés dátuma: 2019.11.15.) 
KSH: TimeSeries of Annual, Regional Statistics - Population, Vital Events/6.1.1.Resident Population By Sex, 1 January (20012018). 2019b. http://www.ksh.hu/ stadat_annual_6_1, (Letöltés dátuma: 2019.11.15.)

Kurnia, S. - Rahim, M. - Hill, S. - Larsen, K. - Braun, P. - Samson, D. - Singh, P.: Supporting Regional Food Supply Chains with an E-Commerce Application. In: Social Inclusion An Usability Of ICTEnabled Services. Routlegde, 2018

Megicks, P. - Memery, J. - Angell, R. J.: Understanding Local Food Shopping: Unpacking the Ethical Dimension. Journal of Marketing Management. 2012. 28 (3-4) 264-289. DOI: https://doi. org/10.1080/0267257X.2012.658838

Miranda, M. - Lawson, R.: Revealing the Lifestyles of Local Food Consumers. British Food Journal. 2012. 114 (6) $816-825$. DOI: https://doi. org/10.1108/00070701211234345

NAK: Helyi termék kézikönyv. Nemzeti Agrárgazdasági Kamara, Budapest, 2016. 76.

NÉBIH: Helyi termelői piac nyitásával, üzemeltetésével kapcsolatos tudnivalók. Élelmiszer értékesítés feltételei a helyi termelői piacon. 2018. https://www. nak.hu/kiadvanyok/tisz/2618-nak-piacforum-nebih-20181204/file (Letöltés dátuma: 2019.09.10.)

Nielsen Report: Future Opportunities in FMCG E-Commerce. 2019. https:// www.nielsen.com/ssa/en/insights/ report/2018/future-opportunities-infmcg-ecommerce/ (Letöltés dátuma: 2019.07.31.)

Pakravan-Charvadeh, M. R. Mohammadi-Nasrabadi, F. Gholamrezai, S. - Vatanparast, H. - Flora, C. - Nabavi-Pelesaraei, A.: The Short-Term Effects of COVID-19 Outbreak on Dietary Diversity and Food Security Status of Iranian Households (A Case Study in Tehran Province). Journal of Cleaner Production. 2021. 281 124537. DOI: https://doi.org/10.1016/j. jclepro.2020.124537.
Renting, H. - Marsden, T. K. - Banks, J.: Understanding Alternative Food Networks: Exploring the Role of Short Food Supply Chains in Rural Development. Environment and planning A. 2003. 35 (3) 393-412. DOI: https://doi.org/10.1068/ a3510

Rizou, M. - Galanakis, I. M - Aldawoud, T. M. S. - Galanakis, C. M.: Safety of Foods, FoodSupplyChainandEnvironment Within the COVID-19 pandemic. Trends in Food Science \& Technology. 2020. 102 293-299. DOI: https://doi.org/10.1016/j. tifs.2020.06.008.

Shahbandeh, M.: Consumer Willingness to Pay for Locally Grown Fresh Produce in Canada 2020. 2020. https://www.statista. com/statistics/1188589/consumerwillingness-to-pay-premium-for-localproduce-canada/ (Letöltés dátuma: 2021.10.12.)

Statista RD.: Share of People Who Prefer to Eat Locally Produced Food in France 2018. 2020. https://www.statista.com/ statistics/1039915/favoring-locallyproduced-food-even-if-fewer-france/ (Letöltés dátuma: 2021.10.11.)

Tregear, A. - Ness, M.: Discriminant Analysis of Consumer Interest in Buying Locallyproduced Foods. Journal of Marketing Management. 2005. 21 (1-2) 19-35. DOI: https://doi. org/10.1362/0267257053166811.

USDA: Farmer Market Managers Highlights. The National Agricultural Statistics Service (NASS), Agricultural Statistics Board, United States Department of Agriculture. 2020. https://downloads.usda.library. cornell.edu/usda-esmis/files/pz5ohd694/ gx41n $598 \mathrm{k} / \mathrm{jd} 473 \mathrm{j} 98 \mathrm{z} / \mathrm{nfaro} 820 . \mathrm{pdf}$ (Letöltés dátuma: 2021.10.12.)

Weatherell, C. - Tregear, A. - Allinson, J.: In Search of the Concerned Consumer: UK Public Perceptions of Food, Farming And Buying Local. Journal of Rural Studies. 2003. 19 (2) 233-244. DOI: https://doi. org/10.1016/So743-0167(02)ooo83-9 
Woodruffe-Burton, H. - Wakenshaw, S.: Revisiting Experiential Values of Shopping: Consumers' Self And Identity. Marketing Intelligence and Planning. 2011. 29 (1) 69-85. DOI: https://doi. org/10.1108/02634501111102760

Wunsch, N. G.: Share of Respondents Who Prefer to Eat Locally-Produced Food in Selected European Countries as of September 2018. 2019. Statista. https:// www.statista.com/statistics/988047/ respondents-who-prefer-to-eat-localproduce-in-selected-european-countries/ (Letöltés dátuma: 2021.10.11.)
Wunsch, N. G.: Most Important Foods to Buy Local Accordingly to U.S. Consumers in 2019. 2020. https://www.statista.com/ statistics/1008618/consumer-importantfoods-to-buy-local-us/ (Letöltés dátuma: 2021.11.01.)

\section{JEGYZETEK * NOTES}

